Chicago-Kent College of Law

Scholarly Commons @ IIT Chicago-Kent College of Law

All Faculty Scholarship

Faculty Scholarship

March 1995

\title{
Excluding Reasons: Impossible Comparisons and the Law
}

Richard Warner

IIT Chicago-Kent College of Law, rwarner@kentlaw.iit.edu

Follow this and additional works at: https://scholarship.kentlaw.iit.edu/fac_schol

Part of the Jurisprudence Commons

\section{Recommended Citation}

Richard Warner, Excluding Reasons: Impossible Comparisons and the Law, 15 Oxford J. of Legal Stud. 431 (1995).

Available at: https://scholarship.kentlaw.iit.edu/fac_schol/683

This Article is brought to you for free and open access by the Faculty Scholarship at Scholarly Commons @ IIT Chicago-Kent College of Law. It has been accepted for inclusion in All Faculty Scholarship by an authorized administrator of Scholarly Commons @ IIT Chicago-Kent College of Law. For more information, please contact jwenger@kentlaw.iit.edu, ebarney@kentlaw.iit.edu. 


\title{
Excluding Reasons: Impossible Comparisons and the Law
}

\author{
RICHARD WARNER*
}

We know the real lesson to be taught is that the human person is precious and unique; yet we seem unable to set it forth except in terms of ideology and abstraction. ${ }^{1}$

The law excludes reasons. More precisely, it routinely denies the status of legal reason to considerations that, outside the legal domain, unquestionably qualify as reasons. ${ }^{2}$ Take price-fixing. Price-fixing can arguably increase employment, and increasing employment is ordinarily something we have reason to do; however, anti-trust law does not recognize 'it increased employment' as a reason that might justify or excuse price-fixing. ${ }^{3}$ Price-fixing agreements are per se illegal. Two more examples: first, '[i]n the law of free speech, offence at the content of ideas is not a legitimate reason to regulate speech, even if the offence is very widespread and intense'; second, '[a]dministrative law consists in large part of the identification of a range of statutorily irrelevant factors-bases for decision that may not be introduced at all, however pertinent they may seem in the abstract'. ${ }^{5}$ It is natural-but crucially wrong-to think that an underlying comparison of reasons always does, or at least should, justify the exclusion of reasons. Sometimes comparisons justify exclusions; other times, exclusions lack any comparative ground.

Let us first look at an exclusion that is grounded in an underlying comparison and then contrast the non-comparative cases. The contrast clarifies what is at issue. The anti-trust example illustrates an exclusion grounded in an underlying comparison. Anti-trust law refuses, as we noted, to recognize it increases

\footnotetext{
* Scott Altman, David Gerber, Joseph Raz, and Richard Wright made extensive comments on earlier drafts, and I am in their debt. I am also indebted Steven Burton, Ralph Brill, Ruth Chang, Marshall Cohen, Stuart Deutsch, Jim Griffin, Steve Heyman, Linda Hirshman, Marty Levine, Marty Malin, Margaret Radin, Margaret Stewart, Chris Stone, Joan Steinman, Steve Wagner, and Catharine Wells. Earlier versions of this paper were given at Chicago-Kent; the USC-Oxford Law and Philosophy Workshop; and, University of Southern California, Law School Faculty Workshop. I gratefully acknowledge the valuable comments of those audiences. I also gratefully acknowledge the support of the Marshall D. Ewell Research Fund.

1 Iris Murdoch, Sartre: Romantic Rationalist (1987) 143. Murdoch is commenting on Sartre's inability to write a great novel.

2 Steven Burton emphasizes this point in fudging in Good Faith (1993) 35-68 (hereinafter, Burton, fudging). Raz also emphasizes the exclusion of reasons in, for example Joseph Raz, The Morality of Freedom 38-69 (1986).

${ }^{3}$ This example is Sunstein's: Cass Sunstein, 'Incommensurability and Valuation in Law' 92 Mich L Rev 779 (1994).

Id., at 801-2.

5 Id.

Exford University Press 1995 Oxford Journal of Legal Studies Vol 15, No 3
} 
emplcyment' as a reason that can legally justifying or excusing price-fixing; instead, it makes price-fixing agreements per se illegal. It does so because of the anti-competitive potential of such agreements, ${ }^{6}$ and we can see the exclusion of the 'it-increased-employment-reason' as based on the comparative judgement that the anti-competitive consequences of price-fixing provide a better reason to avoid price-fixing, a reason so much better that we do not allow defendants even to argue the 'increasing employment versus anti-competition' issue. " "The "trust" in "antitrust" is the belief that competition functions better than any other alternative system of resource allocation that could be devised and implemented. ${ }^{8}$

The anti-trust example illustrates a comparative exclusion, and exclusion grounded in the judgement that the reasons against price fixing are better than the reasons for it. Some exclusions are non-comparative, not grounded in the judgernent that one set of reasons is better than another. The ground, rather, is the non-comparative judgement that no relevant comparison is possible: we do not compare because we cannot. Non-comparative exclusion forms our focus. It is a central but-until recently-largely overlooked aspect of the law. ${ }^{9}$ Noncomparative exclusion plays a role-arguably and for example-in bankruptcy, contracts, environmental law, family law, free speech, torts, racial discrimination, and sexual equality. ${ }^{10}$ More generally, non-comparative exclusion-exclusion based on the impossibility of comparison-does, and should, play a central role in public decision-making.

\footnotetext{
${ }^{6}$ Id., at 801.

7 Similar remarks hold for offensive speech. Given the harm offensive speech can cause, we certainly have reasons to take steps to minimize offensive speech. There are various means to doing so-education, social censure, and, of course, government regulation. So, our reasons to minimize offensive speech are reasons to regulate it. But '[i]n the law of free speech, offense at the content of ideas is not a legitimate reason to regulate speech, even if the offense is very widespread and intense.' Sunstein above $\mathrm{n} 3$ at 801 (emphasis added).

${ }^{8}$ Don Boudreaux \& Robert B. Ekeland, Jr, 'Inframarginal Consumers and the Per Se Illegality of Vertical Restraint:' 17 Hofstra L Rev 137, 153 (1988).

9 The Aollowing list is representative of discussions of the impossibility of comparing reasons: Sunstein above $n$ 3; Margaret Jane Radin, 'Compensation and Commensurability' 1993 Duke L $\mathcal{f} 56$ (hereinafter, Compensation; Donald T. Hornstein, 'Reclaiming Environmental Law: A Normative Critique of Comparative Risk Analysis' 92 Colum L Rev 562, 601-5 (1992); Donald R. Korobkin, 'Value and Rationality in Bankruptcy Decisionmaking', $33 \mathrm{Wm}$ and Mary L Rev 333, 341-2, 352-3 (1992); Richard Warner, 'Incommensurability As A Jurisprudential Puzzle', 68 Chi-Kent L Rev 147 (1992); Scott Altman, '(Com) modifying Experience', 65 So Cal L Rev 293 (1991); John Finnis, Moral Absolutes (1991) (hereinafter, Absolutes); Richard Pildes \& Elizabeth S. Anderson, 'Slinging Arrows at Democracy: Social Choice Theory, Value Pluralism, and Democracy,' 90 Colum L Rev 2121, 2145-66 (1990); John Finnis, 'Natural Law and Legal Reasoning', 38 Cleveland St L Rev 1 (1990) (hereinafter, Legal Reasoning); David Luban, 'Incommensurable Values, Rational Choice, and Moral Absolutes', $38 \mathrm{Clev}$. St $L$ Rev (1990); John Finnis', Concluding Reflections' 38 Clev St L Rev 231 (1990) (hereinafter, 'Reflections); Donald Fiegan, 'Authority and Value: Reflections on Raz's Morality of Freedom', 62 S Cal L Rev 995, 1056-75 (1989); Joseph Raz, 'Facing Up: A Reply' 62 S Cal L Rev 995, 1056-75 (1989) (hereinafter, Facing Up); Christopker Stone, Earth and Other Ethics (1988); Grisez, Boyle \& Finnis, 'Practical Principles, Moral Truth, and Ultimate Ends', 32 Am f furis 93 (1987); Margaret Radin, 'Market-Inalienability', 100 Harv L Rev 1849 (1987) (hereinafter, 'Inalienability'); James Griffin, Well-Being 75-92 (1986); Joseph Raz, The Morality of Freedom (1986) (hereinafter, Freedom); Charles Taylor, 'The Diversity of Goods)' Charles Taylor Philosophy and the Human Sciences 230, 243 (1985); Michael J. Perry, 'Some Notes on Absolutism, Consequentialism, and Incommensurability', 79 Nw U L Rev 967 (1984-5); John Finnis, The Fundamentals of Ethics (1983); John Finnis, Natural Law and Natural Rights (1980).

${ }^{10}$ See Korobkin above $\mathrm{n} 9$ (bankruptcy); Warner, above $\mathrm{n} 9$ at 165-7. Horstein above $\mathrm{n} 9$ at $602-4$ (contracts); 629-33 (environmental law); Sunstein above n 3 at 829-34 (free speech); Radin above $n 9$ (torts); Sunstein above n 3 at 828-9, 850-1 (racial discrimination); and id, at 847-9 (sexual equality). Forthcoming work from Scott Altman discusses the place of incommensurability in family law.
} 
The problem-the problem that motivates this essay-is that the non-comparative exclusion has almost no recognized place in public decision-making, in 'policy discourse in the heart of government, where crucial questions about our shared future are decided'. ${ }^{11}$ A recent Environmental Protection Agency report illustrates the prevailing disregard. ${ }^{12}$ The report insists that we catalogue and compare our reasons-all our reasons-for and against various environmental options. The proposed comparative method is a version of quantified cost-benefit analysis that the report calls 'risk analysis'. Risk analysis purportedly 'allows many environmental problems to be measured and compared in a common language, and it allows different risk reduction options to be evaluated from a common basis'. ${ }^{13}$ The report warns against the serious danger of not employing such a comparative approach: 'If finite resources are expended on lower-priority problems at the expense of higher priority risks, then society will face needlessly high risks'. ${ }^{14}$

All reasons are supposed to be grist to risk-analysis's comparative mill. But what if it is impossible to compare some of the reasons we pour in the riskanalysis machinery? Then the real risk is that decision-makers blindly committed to comparison will fall victim the illusion that a comparison of reasons justifies their list of priorities. ${ }^{15}$ The danger is not merely that impossibility of comparison will go unnoticed-although that is danger enough to motivate serious concern. The openness to criticism that is the life-blood of democratic decision-making requires clarity about the true grounds of public policy. But the danger goes deeper. To ignore the impossibility of comparison is to ignore the value and dignity of individual persons. Policy discourse which denies non-comparative exclusion erases the value of individuals out of its policy-making equations. What is at stake in the plea to recognize non-comparative exclusion is ourselves.

To put the point more positively, to recognize the role of non-comparative exclusion in public policy is to recognize that the inviolable value of individuals substantively constrains public decision-making. To some--perhaps to manythis position will seem passé; for example, in commenting on opposition to costbenefit analysis, Robert Bellah remarks that

opponents of the cost-benefit approach to public policy invoke embedded cultural traditions, a sense of moral and religious absolutes. ... The ... vision of cost-benefit analysis is countered with a deeply rooted moral individualism that respects the dignity

11 Robert N. Bellah et al, The Good Society (1991) 120.

12 Science Advisory Board, US Envtl Protection Agency, Pub No. 91-155259, Reducing Risk: Setting Priorities and Strategies for Environmental Protection App A (Sept. 1990).

13 Id. at 2.

14 Id.

15 The risk is a practical reality. The National Academy of Sciences has identified fifty different points at which those engaged in risk assessment must make a choice among competing scientific judgments about uncertain data or unclear theoretical connections. Mary L. Lydon, 'Risk Assessment, Risk Communication and Legitimacy: An Introduction to the Symposium', 14 Colum $f$ Envtl. L 289, 291 (1989). As Hornstein notes, 'critics view the results suspiciously, as artifacts of the chosen methodologies rather than as representations of reality'. Hornstein above $\mathrm{n} 9$ at 573 . Hornstein also notes that ' $[\mathrm{t}] \mathrm{he}$ legal literature on risk analysis has generally skirted the normative difficulties raised when risk is used as the common metric of governmental programs that protect human health and safety'. Id, at 564. 
of persons, but has largely lost the social context of the older traditions. This has little to offer in dealing with the complexity of interrelated choices a modern society must make, and therefore is not an effective alternative to cost-benefit analysis. ${ }^{16}$

These remarks readily generalize beyond cost-benefit analysis. As Amartya Sen notes,

[i]n the revival of rights-based ethics in recent decades, rights have often been seen in deontological terms, taking the form of constraints that others simply must obey. It is arguable that this type of deontological structure may not be particularly suitable for focusing on complex problems of pervasive interdependence involved in social morality. ${ }^{17}$

Against Bellah and Sen, I claim that non-comparative exclusion involves a viable appeal to value, not a moribund return to discarded traditions. In defending this claim, I put to one side the diverse list of topics we noted at the beginning (bankruptcy, contracts, environmental law, family law, free speech, torts, racial discrimination, and sexual equality). Non-comparative exclusion is crucially relevant to these issues, but, before we can usefully turn to those issues, we first need a deeper understanding of non-comparative exclusion. My concern is to show what it is, and that it occupies an important place in public decisionmaking. I will not be concerned with issues about how to decide particular questions of public policy.

Section I presents an example of non-comparative exclusion. Section II argues for the compatibility of non-comparative exclusion with rational decision-making. Section III examines four instances of non-comparative exclusion in the law, and Section IV concludes with a plea for the recognition of non-comparative exclusion in public decision-making.

\section{An Example of Non-Comparative Exclusion}

An example of non-comparative exclusion is in order, an example that clarifies what is at issue. To this end, consider $\$ 7409$ of the Clean Air Act. That section directs the EPA Administrator to set natural ambient air quality standards (NAAQS) at levels necessary to protect public health and welfare; and, in determining the levels, the Administrator is not required to consider the feasibility (technological and economic) of meeting the standard. ${ }^{18}$ The Administrator may exclude reasons of technological and economic feasibility. Of course, to say just this much is not yet to produce a clear case of non-comparative exclusion. We could still see the exclusion of reasons in $\$ 7409$ as similar to the exclusion of reasons in the anti-trust example; we could, that is, see an underlying comparison

${ }^{16}$ Bellah above $\mathrm{n} 11$ at 120 (emphasis added)

17 Amartya Sen On Ethics $\&$ Economics (1987) at 71-2.

1842 USC $\$ 7409$ (1990). In Lead Industries Assoc v Environmental Protection Agency, 647 F, 2d 1130 (1980) the court holds nothing in the language of the section suggests that the Administrator should consider economic or technological feasibility in setting standards. 
of reasons as rationalizing the exclusion. Indeed, why not see the legislature as having made the relevant comparison when passing $₫ 7409$ ?

The legislature was certainly confronted with reasons both for and against imposing infeasible standards. The infeasibility 'reasons against': infeasible standards burden the affected industries in ways that can have adverse economic effects (eg less effective international competition; lost jobs; the closing of entire factories), and these adverse economic consequences provide a reason against imposing infeasible NAAQS. The health 'reasonsfor': imposing infeasible standards protects public health and welfare by providing the affected industries with an incentive to develop better and cheaper pollution control technology, and providing the incentive serves as a reason for imposing the standard. ${ }^{19}$ Why not see the legislature as having passed $₫ 7409$ because it thought the reasons for it were better than the reasons against it? On this view, $₫ 7409$ excludes the feasibility reasons simply because the legislature did not want the Administrator secondguessing its considered legislative judgement. The legislative history in fact suggests that the legislature did attempt to make such a judgement. ${ }^{20}$

But that does not matter. The essential point is that the legislature could not have had any adequate rational ground for such a judgment. Whether the health reasons are better than the infeasibility reasons depends on detailed facts about the state of technology and the state of the economy; moreover, these facts will vary from industry to industry, and they will vary over time as technology develops and the economy changes. Even if the legislature could have determined, at the time of passing $₫ 7409$, that the health reasons are better than the infeasibility reasons, the legislature could not possibly reliably determine this for the future. If the legislature tried to make such a judgment, it tried to do the impossible. Some may object that the legislature need not make such a judgment forever. The amendment process allows adjustment. But this will not do. The amendment process is slow and not sufficiently responsive to rapidly changing conditions varying over a variety of industries. We cannot rationalize the exclusion by appealing to a comparative judgment. The Clean Air Act shows the law speaking with a confidence that cannot rationally rest on an underlying comparison of reasons. ${ }^{21}$

How then can we see the exclusion as rational? How could a legislaturerationally-allow the EPA Administrator to exclude feasibility considerations?

\footnotetext{
19 This was one of the legislative motives behind the Clean Air Act. See $H R$ Rep No 294, Cong, Ist Sess 106-10, 133-36 reprinted in US Code Cong. E Admin News (1977) 1077, 1184-8, 1211-15.

${ }^{20}$ See David P. Currie, 'Degradation and Visibility Under the Clean Air Act', 68 Cal L Rev, 48, 70-6 (1988) (discussing legislative attitudes behind various provisions of the Clean Air Act).

${ }_{21}$ Two more examples. First: the Endangered Species Act almost entirely forbids relevant comparisons. Endangered Species Act of 1973, Pub L No 93-205, 87 Stat 884 (codified as amended principally at 16 USC $\$$ $\$ 1531-44$ (1988)). Sunstein above $n 9$ at 835 also cites this example. Second: The Delancy Clause bans the entry of carcinogens into the market no marter what the gain from allowing entry. Food Additive Amendments Act of 1953, Pub L No 85-929 \4, 72 Stat 1784 (codified as amended at 21 USC $₫ 348$ (c)(3)(A) (1988). Sunstein above $n$ example of non-comparative exclusion in virtually any area of the law.
} 
Non--comparative exclusion provides the answer. Where a comparative judgement cannot rationalize the exclusion, a non-comparative judgement, the judgment that no comparison is possible, may still do so. On this view, we do not demand that the Administrator compare feasibility reasons to health reasons; they cannot be compared as better, worse, or equally good. We allow the Administrator to exclude the reason so as to avoid demanding an impossible comparison..$^{22}$ It is worth emphasizing that this sort of appeal to the impossibility of comparison is common in environmental law. ${ }^{23}$ In American Can Co. v Oregon Liquor Control Commission, ${ }^{24}$ for example, the Oregon Court of Appeals contended that

[t]he blight of the landscape, the appropriation of lands for solid waste disposal, and the injury to children's feet caused by pull tops discarded in the sands of our ocean shores are concerns not divisible by the same units of measurement as is economic loss to elements of the beverage industry and we are unable to weigh them, one against the other. ${ }^{25}$

As James Huffman remarks (unsympathetically), '[a] favorite principle of orthodox environmentalists is that environmental values and economic values are incommensurable'. ${ }^{26}$ Seeing $\ 7409$ as recognizing a non-comparative exclusion is of a piece with, to use Huffman's label, the 'orthodox environmentalist' appeal to the impossibility of comparison. Of course, for us, environmental law is merely an example-albeit, a particularly apt one. Our concern is with non-comparative exclusion generally. We offer $₫ 7409$ as an example, as an example of the exclusion of reasons rationally grounded, not in a comparative judgement that one set of reasons is better than another, but in the non-comparative judgement that no relevant comparison of reasons is possible.

But does the example really serve this purpose? Two objections demand consideration here. The first is easily answered; the second goes to the heart of the matter. The first objection is that there is no need to claim that it is impossible to compare the 'health' and 'feasibility' reasons; rather, there is a much simpler explanation of the $₫ 7409$ exclusion. We could see the legislature as having decided that the health reasons to have clean air are immensely strong, and as also having decided that the risk was great that, in setting NAQSS, the EPA Administrator would, when confronted with economic and technological reasons against an infeasible NAQSS, wrongly see the health reasons as weaker than they actually are. $\$ 7409$ guards against this error by allowing the Administrator

\footnotetext{
${ }^{22}$ Some will object of course that the section says the Administrator may exclude feasibility reasons, not that he or she must do so. Isn't 'must' what we should expect if the comparison is truly impossible? Not necessarily. The 'may' may reflect the conviction that comparison is often or typically-but not always-impossible. The point could be to give the Administrator the discretion to decide in which cases comparison is called for, in which it is impossible. We might allow such discretion if we know that feasibility reasons were sometimes excluded but were not sure exactly when.

${ }^{23}$ See eg Bailey H. Kuklin, 'When Incommensurable Values Conflict-Thoughts On Mandelker's Envimnment and Equity: A Regulatory Challenge', 49 Brooklyn L Rev 245, 253 (1983) ('The most questionable use of the costbenefit analysis arises when incommensurable, noneconomic values must be balanced against the hard dollar claims of development.').

2415 Or App 618 (1973).

25 Id a: 630 .

${ }^{26}$ James L. Huffman 15 Harv $\mathcal{F}$ of $L$ E Pub Pol 349, 366 (1993).
} 
to exclude the economic and technological reasons. Why not see this as the explanation the exclusion? Indeed, one might suggest that legislatures typically engage in such 'risk of error analysis', and that they typically do not compare reasons. Legislatures-the suggestion is-hope to avoid large errors, not to achieve a precise comparison of reasons. ${ }^{27}$

The problem with this objection is that risk of error analysis does not avoid, but actually requires, a comparison of reasons. To see why, consider the effect of excluding the feasibility reasons. Imagine the Administrator considering an infeasible NAQSS; he or she will have health reasons to impose the NAQSS, and no feasibility reasons-no feasibility reasons that get considered-not to. So, insofar as he or she is rational, the Administrator will impose the NAQSS. The crucial point is that, if the feasibility reasons are really better than the health reasons, the Administrator's decision will be a mistake. On the risk of error analysis, this is just the kind of mistake-the misevaluation of reasons-the legislature is trying to avoid in excluding the feasibility reasons. But how can it be confident that the exclusion will avoid this error? It cannot-unless it knows that the health reasons are generally better than the feasibility reasons. Risk of error analysis cannot avoid a comparison of reasons; rather, it requires it, and, as we argued earlier, the $\$ 7409$ exclusion cannot rest on a comparative judgement that one set of reasons is better than another.

We should see the exclusion as resting on the judgement that no comparison is possible. That non-comparative judgement rationalizes the exclusion. But how? How does it reveal the exclusion as rational? This is the second, and far more serious, objection. The problem is that excluding feasibility from consideration seems patently irrational. After all, we have reasons for and against imposing infeasible standards. It certainly seems that rational decision-making requires comparing the 'reasons for' to the 'reasons against' to determine which is better. But this is precisely the comparison $₫ 7409$ says is not required, and our suggested 'non-comparative exclusion' explanation says is impossible. So, if rational decision-making requires comparison, and if the reasons to be compared cannot be compared, that 'cannot' condemns us to irrationality. This threat of irrationality is not real. Non-comparative exclusion does not condemn us to irrationality. To see why, we first need to see the sense of 'cannot' in which we cannot compare reasons. This is the key to understanding non-comparative exclusion and its role in public decision-making.

\section{The Case For Non-Comparative Exclusion}

In what sense, then, is it true that we sometimes 'cannot' compare reasons as better, worse, or equally good? A temporary change of focus yields the answer. Our opening survey of non-comparative exclusion focused on public decisionmaking; however, personal decision-making is the primary and most natural

\footnotetext{
${ }^{27}$ I am indebted to Scott Altman for raising and discussing this objection.
} 
domain of non-comparative exclusion. We need to turn our attention to the personal to see clearly the sense in which we 'cannot' compare reasons.

\section{$A$ The Meaning of 'Cannot'}

An example is helpful. Suppose that, as I am out walking with my daughter, a stranger approaches and offers me a $\$ 1,000,000$ if I will turn her over to him and never see her again. I refuse, and the stranger then makes the same offer to Jones. Jones has a reason not to sell his daughter: he would miss her. However, Jones also has a reason to have the money; he would pay off bills and invest the rest; and, since getting the money means selling his daughter, he sees these financial considerations as a reason to sell his daughter. He compares his reasons for and against selling his daughter; finds his reason not to sell to be the better one, and accordingly refuses the stranger's offer. But, as Jones candidly acknowledges, the result would have been otherwise had the price been sufficiently high-say, one billion dollars.

My refusal might be thought to rest on similar grounds. I also have a reason not to sell my daughter: I love her; and, I also have a reason to have the money: I too would pay off bills and invest the rest. However, unlike Jones, my decision results not from comparing, but from excluding reasons. Just as if I were a court excluding reasons, I regard the financial considerations as irrelevant to my decision - as, I can assure you, I really would, were the situation in this example ever actually to arise. When I exclude the reason, I proceed exactly as if the money provided no reason at all to sell my daughter. So my decision is simple: I have a reason not to sell (my love for my daughter), and no reason-no reason I will consider-to do otherwise; accordingly, I refuse the stranger's offer ${ }^{28}$

Now, merely describing this example does not-even with my assurance that I really would exclude the reason-show that my refusal rests on the noncomparative exclusion of the reason. For all we have said so far, the exclusion could-like the exclusion in the anti-trust example-rest on an underlying comparison of reasons. The key to seeing that this is an example of noncomparative exclusion lies in seeing why I exclude the reason. The answer: I exclude the reason because of my commitment to my daughter-my love for her; I would not love her-at least, not in the way I do-if I counted the money as a reason to sell her. It is definitive, constitutive, of my commitment that I exclude the reason. Now, this answers one question simply to raise another: why is the exclusion definitive of the commitment? But let us briefly defer answering this second question.

\footnotetext{
${ }^{28}$ Of course, I also have moral reasons to refuse; it is morally wrong to sell my daughter. My point is that my commitment also leads me to refuse to sell.
} 
We should first emphasize a crucial point: namely, we can now explain the sense in which I cannot compare reasons. I cannot compare in the sense that I cannot do so consistently with my commitment. My commitment requires that I exclude the money as a reason, and I cannot simultaneously exclude the reason and also compare it to other reasons. To see why, suppose I were to treat the comparison of reasons as relevant to my decision; suppose, that is, that I see the comparison of reasons as determining, at least in part, whether I will sell my daughter. To so regard the comparison is to treat the financial considerations as a reason to sell my daughter, and that is precisely what my commitment does not allow. To compare a reason is not to exclude it.

Some will object that we have cheated here. What we have shown is that the comparison of reasons cannot play any role in my decision. The objection is that this is not the same as showing the comparison is impossible. Why couldn't I see the reasons as comparable-although not in a way relevant to deciding whether to sell my daughter? There is no need to settle this issue. What we care about is the comparison relevant to deciding what to do. A comparison of reasons irrelevant to decision-making is hardly worth consideration. ${ }^{29}$

Of course, this entire explanation of the sense in which I cannot compare depends on the claim that excluding reasons is definitive of my commitment to my daughter. Why is that true? The short answer is, that is just what parental love is. More fully, as Joseph Raz remarks,

[f] or many, having children does not have a money price because exchanging them for money, whether buying or selling, is inconsistent with a proper appreciation of the value of parenthood. ... [B] oth their rejection of the idea that having children has a price and their refusal even to contemplate such exchanges are part of their respect for parenthood, and of the very high value they place on having children. ${ }^{30}$

We care-indeed care a great deal-about whether a father is the sort of person that would see financial gain as a reason to sell his daughter. When differences are sufficiently important to us we often have a concept that marks the difference, and we do here. 'Parental love' designates the difference, and, of course, it is the difference that matters, not the words that name it. If someone wants to insist that Jones, who would sell his daughter for a sufficiently high price, can be described as 'loving' his daughter, we have nothing to argue about as long as we recognize the difference and its significance.

\footnotetext{
${ }^{29}$ I suggest this as an explanation of incommensurability, a concept that has received much discussion recently. See above $\mathrm{n}$ 9. Reasons are incommensurable when they cannot be compared as better worse or equally good. Compare Raz, Freedom, above $\mathrm{n} 9$ at 122: 'A and B are incommensurate if it is neither true that one is better than the other nor true that they are of equal value'. Note that we define incommensurability as a relation between reasons, not-as Raz does-in terms of value. The two approaches are largely intertranslatable; indeed, Raz is quite willing to describe reasons as incommensurable in this sense. Id, at 338,340 . The problem with incommensurability is to explain why reasons cannot be compared. The text does so. Some may object the text explanation is not really an explanation of incommensurability since the text only makes comparison impossible relative to a commitment, not impossible simpliciter. I do not see this as a defect.

${ }^{30}$ Raz above $n$ 9, at 348.
} 
Another caveat is in order to avoid another misunderstanding. I do not claim that there are no circumstances in which one might sell a child one loves. Suppose Sally has two daughters; one will die if she does not receive medical treatment costing $\$ 1,000,000$. Sally might sell the healthy daughter to raise the money. But she would still not be like Jones. Jones recognizes the financial reasons to have the money as reasons to sell his daughter; Sally recognizes saving the life of one child as a reasons to sell the other. In the daughter-selling example, the financial considerations-paying off bills and having money to invest-are the considerations I reject as reasons to sell my daughter. If my daughter's life would be better with the stranger, that-perhaps-would be a reason to sell her. I am not claiming that nothing can be a reason to sell one's daughter, and, more generally, I do not mean to suggest that what parental love allows and disallows as a reason is well-defined. That is certainly not true; in general, one discovers case by case what one will and will not count as a reason. The essential point is that excluding reasons-possibly different reasons for different people-defines in part parental love. Given such a commitment, one cannot, cannot consistently with the commitment, compare the excluded reasons to reasons one recognizes as legitimate bases for action. So I claim.

But surely this claim simply overlooks an obvious way in which an underlying comparison could explain the exclusion. Consider the commitment itself. I do have reasons for that commitment, and, given that I persist in the commitment, I must judge those reasons to be better than the reasons against having the commitment. Why not take this as the comparative judgment that underlies my excluding the money as a reason to sell my daughter?

In reply, it is worth noting first that sometimes-often, perhaps-we do not form our commitments for reasons. To speak overtly autobiographically: my commitment to my daughter took hold when I saw her born; the commitment simply happened; no path of reasons lead me to it. Of course, we could and sometimes do form commitments as the result of reasoned reflection; and, even in the case of my commitment to my daughter, I can-now-give reasons for it, even if those reasons did not generate it. However, my reasons for having my commitment to my daughter are very general considerations about the pleasure and value of having a daughter; they do not contain or constitute a comparison of reasons to sell my daughter with reasons not to. Indeed, they could not constitute such a comparison. Suppose-arguendo-that they did. The result would be a contradiction. I would be committed to not counting as reasons to sell my daughter the very considerations that, in making the comparison, I am countiug as reasons. ${ }^{31} \mathrm{My}$ commitment to my daughter creates a non-comparative exclusion; no underlying comparison explains the exclusion.

\footnotetext{
31 It is essential here that we imagine my commitment to be in full force. We are not imagining a case in which, under the impact of the strangers offer, my commitment weakens or changes. In the latter cases, I may consider the money as a reason to sell. I am indebted to Scott Altman for emphasizing the importance of these issues about reasons and commitments.
} 
A final objection remains, however, an objection that has enjoyed some prominence in the literature. ${ }^{32}$ The objection (in the form relevant here) ${ }^{33}$ is that we have misdescribed my commitment to my daughter. Why not simply say that my commitment is to regard my daughter as worth an infinite amount of money? Then we could say that I do compare reasons when I refuse to sell her, but that, as long as the amount of money is finite, my reason not to sell my daughter always outweighs those considerations. Only an infinite amount of money could provide a reason that would be better than my reason to keep my daughter, and having an infinite amount of money is, of course, impossible.

In reply, first ask what means to say I value my daughter 'infinitely'? It means simply I will always refuse to sell her for any finite amount of money; this is the only meaning given to talk of 'infinite valuing' in the objection. Once this is clear, the objection collapses. We need only ask, why will I always refuse? We cannot answer 'Because I value her infinitely'. That is just to produce as an explanation the very thing to be explained; for, as we just noted, to say that I value my daughter 'infinitely' is just to say that I will always refuse to sell her for any finite amount of money. This 'objection' does not confront us with an alternative - comparative-explanation of my refusal to sell my daughter; instead, it is simply a misleading redescription of the phenomenon for which noncomparative exclusion provides a genuine explanation. Without an alternative explanation, there is no objection.

\section{B Non-Comparative Exclusion and Rationality}

One crucial question remains: how can the non-comparative exclusion of reasons be rational? We have shown that we can make commitments-such as my commitment to my daughter - that create incommensurabilities. But should we make such commitments? Is it rational to do so? The question is critical to evaluating the place of non-comparative exclusion in public decision-making. Our claim is that non-comparative exclusions are consistent with, and indeed sometimes essential to, rational public decision-making. So, can a non-comparative exclusion of reasons be rational?

Clearly it can. Indeed, it would be bizarre to suggest that it is irrational for me to love my daughter. Of course, it is clearly possible to have compelling reasons not to love one's daughter; one's love might be a destructive love that is destroying both father and daughter, for example. But, even if this is a case

\footnotetext{
32 Donald Regan advances this objection. Regan is 'inclined to think all values are commensurable' (Regan above 9 at 1056) because he thinks claims of the impossibility of comparison arise out of a misunderstanding and misdescription of what is really a comparison. Regan contends that, when one someone claims, for example, that friendship is not comparable in value to money, 'such a person is most likely to mean that friendship is more valuable than any amount of money, or in other words, that the value of friendship is incomparably greater'. Id at 1058. Of course, by 'incomparably greater' Regan does not mean that there is no comparison; he means, when we do compare the values, one value so greatly outweighs the other that it creates the illusion of a genuine case of the impossibility of comparison. Sunstein takes this objection to be a central objection to claims about the impossibility of comparison. Sunstein above $n 9$ at 830.

${ }^{33}$ I have recast the Regan objection in terms relevant to our discussion, in terms of commitment and exclusion of reasons.
} 
in which it is contrary to reason to love one's daughter, such cases are not what is at issue here. The issue is whether-assuming a healthy, non-pathological love-rationality requires that I regard the $\$ 1,000,000$ as reason to sell her. To think this would be to think that rationality requires that I should not love my daughter, and that is absurd. The selling-my-daughter example is a case of rational, non-comparative exclusion of reasons. It is clearly beyond question that non-comparative exclusion of reasons can be rational (which is not, of course, to say it is rational in every case). ${ }^{34}$

Such non-comparative exclusions play an essential role in our everyday relations with each other. Wherever there is commitment to a person or to a way of life for oneself, we are likely find the exclusion of reasons. ${ }^{35}$ As Raz contends, noncomparative exclusions of reasons,

mark out areas which are out of bounds for anyone interested in the personal relations and the pursuits of which they are constitutive. Here failure of commensurability is a success. It is impoverishing to compare the.value of marriage with an increase in salary. It diminishes one's potentiality as a human being to put a value on one's friendship in terms of improved living conditions. In these cases incommensurabilities are not just part of the inevitabilities of life. They are part of the building blocks of valuable pursuits and relationships. ${ }^{36}$

We should add to Raz's remarks that non-comparative exclusions of reasons often lie at the centre of the self. ${ }^{37}$ This point is essential to appreciating the place of non-comparative exclusion in public decision-making.

\section{Non-Comparative Exclusion and the Self}

The daughter-selling example illustrates the relation between non-comparative exclusion and the self; for, it would be natural to express the difference between me and the potentially-daughter-selling Jones by saying that we are very different

\footnotetext{
${ }^{34}$ An arguably irrational commitment: Mason is a gourmet who works as a restaurant reviewer for newspapers and magazines. His doctor tells him he has gout and must, on pain of destroying his health, stop eating the rich French tood in which he delights. But Mason persists in his gourmet pursuits; he thinks of himself as a badly injured warrior who, although doomed to defeat, defiantly refuses to cease fighting for his ideal - the ideal for the gourmet Mason being the refinement of appetite as a source of pleasure. Mason takes this commitment to such an extreme that he excludes the health considerations as a reason. He takes pride in this, seeing it as a sign of the depth of his commitment. Mason's dismayed friends try to argue him out of his destructive course. They emphasize that he has other important goals besides the refinement of taste as a source of pleasure, and that continued health is essential to the effective pursuit of these goals. Their point is that it is irrational for Mason to destroy his health in the pursuit of the pleasures of taste. Some will think the friends are right; some will not. We need not resolve this issue.

${ }^{35}$ Loyalty is a good example. Imagine you, as president of a company, must entrust crucial trade secrets to an employee. You have two candidates. Both can be described as loyal. But one is loyal to the company in the sense that she excludes financial gain as a reason for disloyalty. This is not true for the other employee. He is not loyal in this sense. He sees financial gain as a reason but, so far considerations of financial gain have been outweighed by his reasons to be loyal. Whom would you be more likely to trust?

${ }^{36} \mathrm{Raz}$ makes this point when talking about what he calls 'constitutive incommensurabilities.' Raz above $\mathrm{n} 9$ at 345-57. Constitutive incommensurabilities involve the exclusion of reasons. Id at 346-7.

37 Margaret Radin has repeated emphasized the role of personhood in explaining the resistance to commodification. Radin, 'Inalienability' above $\mathbf{n} 9$.
} 
people. Commitments-to children, to friends, to ideals-are typically commitments involving non-comparative exclusion, and they are also typically commitments through which we define who we are. For example, suppose someone suggests that, in an upcoming committee meeting, you should vote as political expediency demands, not as your conscience dictates. You refuse, for your commitment to following your conscience requires excluding reasons of mere political expediency. Indeed, you respond with shock and outrage, 'I cannot do that. What would ever make you think I could? What sort of person do you think I am?' As the example shows, we define our identities both by the reasons we accept and the reasons we exclude.

This is not to say that every reason-excluding commitment lies at the centre of our self-definition. For example, one might be-as indeed many arecommitted to maintaining one's health in a way the excludes financial considerations as reasons to forego needed treatment, but this commitment need not figure prominently in one's sense of one's identity. Commitments form a continuum, ranging from those at the center of our self-definition to those that lie at the periphery. The essential point is that our commitments involving noncomparative exclusions-centrally self-defining or peripheral-ensure that noncomparative exclusion plays a central role in personal decision-making.

For this same reason, non-comparative exclusion also plays a central role in public decision-making, for, as a society, we share commitments-some rational, some perhaps less so-that entail non-comparative exclusions. To see why, simply ask, what sort of State do we wish to live in? One that makes public policy by ignoring the self-defining commitments that make us who we are? Or, one that takes such commitments appropriately into account? Surely the latter. To live in the former State would be to live in a State that served some anonymous and anodyne abstract 'citizen' drained of the self-constituting individuality that defines who we are. The State should serve $u s$, not some 'citizens' who, if they were to exist, would be utterly alien to human individuals. When, for example, the State in ordering custody invokes its power to take my daughter from me and to define the terms on which I may see her, on what grounds do I want the decision made? Should the State regard time with my daughter as fungible with money? Should it see visitation as something to be traded-off against dollars? In making such decisions, I want the State to give due weight to the fact that, in my eyes, my daughter is not for sale. This commitment is definitive of my relationship with my daughter and to ignore it is to ignore the very relationship that should be a focal point of the custody hearing.

All of which raises an interesting empirical question about the law. Does the law take non-comparative exclusion into account the way it should? The answer is, 'On occasion, at least'. Sometimes the law does indeed inextricably weave non-comparative exclusion claims into its response to the 'complex problems of pervasive interdependence involved in social morality'. ${ }^{38}$

\footnotetext{
${ }^{38}$ Bellah above $\mathrm{n} 11$.
} 


\section{Four Examples of Non-Comparative Exclusion in the} Law

I offer four characteristic examples from environmental law, property law, torts, and contracts. The environmental law and property law examples show the law excluding reasons with a confidence that would be utterly misplaced if it were based on a comparison of reasons, a comparison that would at best be unclear and controversial..$^{39}$ Only the recognition of a relevant non-comparative exclusion can justify the confidence. In the torts and contracts examples, on the other hand, a relevant comparison of reasons does not seem unacceptably unclear or controversial, yet the law clearly refuses to make the comparison.

A caveat: I intend the examples as plausible illustrations of the non-comparative exclusion of reasons. I do not offer them as detailed and conclusive pieces of legal analysis. My aim is to illustrate how to see the non-comparative exclusion of reasons in the law; I can do this without incontrovertibly establishing that each example is a genuine instance of non-comparative exclusion.

\section{A Environmental Law}

We return to $₫ 7409$ of the Clean Air Act for the environmental law example. Let us assume, as we argued earlier, that we should see the section as recognizing a non-comparative exclusion. The question now is, what shared commitment could generate this non-comparative exclusion? The answer lies in a widely shared attitude toward and unpolluted and healthy environment. As Cass Sunstein notes, '[s]ome people feel extremely insulted when asked how much [money] they would accept for a specified level of environmental deterioration, treating the question as outrageous or a form of bribery, rather as if they had been asked to sell a child or a part of their body'. ${ }^{40}$ Sunstein cites a 1992 survey in which eighty percent of those polled said they thought we should achieve a clean environment 'regardless of the cost'. ${ }^{41}$

We can explain this attitude in terms of the non-comparative exclusion of reasons-as the following example shows. Suppose you have the legal right to enjoin the pollution of part of the ocean-say, Santa Monica Bay. You are offered $\$ 1,000,000$ to permanently waive that right. You refuse, and your decision results not from comparing, but from excluding reasons. You proceed exactly as if the money provided no reason at all to allow the pollution, so you decision is simple: you have a reason not to allow the pollution, and no reason-no reason you will consicler-to do otherwise. To exclude, in this way, the money as a reason to allow pollution is to think that we should achieve a clean environment 'regardless

\footnotetext{
${ }^{39}$ Finnis makes a similar point: "The task of commensurating the goods and bads involved in alternative options--where this commensurating is proposed as governing, not governed by, moral principles and norms of responsibility-is well beyond human reason's power to encompass. The goods and bads of bringing a child into the world go far beyond those which a couple can envisage as they try to compare not having a child with having one and bringing it up over the next twenty years'. Finnis, Absolutes above n 9 at 18.

${ }^{40}$ Sunstein above $\mathrm{n} 9$ at 835 .

41 Id.
} 
of the cost'. ${ }^{42}$ Non-comparative exclusion explains the force and point of 'regardless of the cost'. We can see the exclusion of reasons in $₫ 7409$ as acknowledging such a commitment to an unpolluted and healthy environment. To fail to acknowledge this commitment would be to make environmental law for us that failed to speak to our environmental concerns, concerns captured in our non-comparative exclusion-creating commitment to an unpolluted and healthy environment.

Of course, there is a middle ground between enacting the non-comparative exclusion into law and completely ignoring it. One can give it due consideration without finally incorporating it into law. The next example illustrates this possibility.

\section{$B$ Property Law}

Moore $\mathrm{v}$ The Regents of the University of California ${ }^{43}$ provides the property law example. In Moore, a UCLA Medical Center doctor treating Moore's leukemia removed Moore's spleen. The spleen contained abnormal genetic material of great commercial value, and, without obtaining Moore's consent, the doctor and medical center marketed the material for a considerable profit. ${ }^{44}$ Moore claimed conversion-supporting the claim with colourable legal reasons to hold he had a property right in the genetic material. ${ }^{45}$ A majority of the California Supreme Court rejected Moore's claim. Moore elicits a non-comparative exclusion claim as a natural and intelligible reaction to the majority's position, a reaction displayed in the dissent.

\section{(i) The majority opinion}

The majority decided the case by comparing reasons. The majority acknowledged that there were reasons-advanced by Moore-to recognize a property right in the genetic material. Moore's basic claim was that the right existed as a corollary of his right to control what happens in and to his body; ${ }^{46}$ he argued the right extended to the genetic material extracted from his spleen. The majority, however, found reasons not to agree. ${ }^{47}$ In particular, they emphasized that researchers use human cell lines stored in vast numbers in tissue repositories. Recognizing Moore's claim would, the majority contends, 'threaten with disabling civil liability innocent parties who are engaged in socially useful activity, such as researchers who have no reason to believe that their use of a particular cell sample is, or

\footnotetext{
42 Id.

$4351 \mathrm{Cal} 3 \mathrm{rd} 120$ (1990).

${ }^{44}$ The doctor was given 75,000 shares of stock in the private company that bought the material, and became a paid consultant for the company. In addition, the doctor and the UCLA together were given $\$ 1,000,000$ over a three year period. Id at 183 .

${ }_{45}$ Id at $156-7,169-70,173-4$.

46 This reason is most clearly discussed by Brousard J. Id at 167-70 (Brousard J, concurring and dissenting).

47 In addition to the 'hindering research and protecting researchers' reason we focus on, the majority advances statutory arguments for denying the property right (id at 158-60), contends that there is no good common law precedent for doing so (id at 34), and that common law actions besides conversion adequately protect the interests of patients in situations like Moore's (id at 160-61).
} 
may be, against a donor's wishes'. ${ }^{48}$ In addition, recognizing the claim would hinder ' $[\mathrm{r}$ ] esearch on human cells [which] plays a critical role in medical research' ${ }^{4}{ }^{9}$ The majority concluded that there was a good reason to deny the property right. It is convenient to have short-hand to refer to these reasons, so call them the 'research' reasons. The majority compared reasons, and, unfortunately for Moore, they found the 'research' reasons to be the better ones.

\section{(ii) The non-comparative exclusion objection}

The majority's comparative approach provoked a strong dissent from Justice Mosk. He contended that

our society acknowledges a profound ethical imperative to respect the human body as the physical and temporal expression of the unique human persona. One manifestation of that respect is our prohibition against direct abuse of the body by torture. ... Another is the prohibition against indirect abuse of the body by its economic exploitation for the sole benefit of another person. The most abhorrent form of such exploitation, of course was the institution of slavery. Lesser forms, such as indentured servitude or even debtor's prison, have also disappeared. Yet their specter haunts the laboratories and boardrooms of today's biotechnological research-industrial complex. It arises whenever scientists or industrialists claim, as defendants claim here, the right to appropriate and exploit a patient's tissue for their sole economic benefit, the right, in other words, to freely mine or harvest valuable physical properties of the patient's boćy: 'Research [of this sort treats] the human body as a commodity - a means to a profitable end. The dignity and sanctity with which we regard the human whole, body as well as mind and soul, are absent when we allow researchers to further their own interests without the patient's participation by using a patient's cells as the basis for a marketable product ${ }^{30}{ }^{50}$

Mosk clearly thought that the majority undervalued - or even simply ignored-the value we place on persons. In his words, the 'dignity and sanctity with which we regard the human whole ... are absent' when we allow the marketing of the genetic material from the spleen.

Mosk's position admits of two interpretations. The first sees him as contending that the majority's mistake consists in comparing wrongly. On this interpretation, Mosk's point would be that the 'dignity' reasons to recognize the property right are better than the 'research' reasons not to. The alternative interpretation sees Mosk as asserting a non-comparative exclusion: the 'dignity and sanctity with which we regard the human whole' mean that we should exclude the 'research' reasons from consideration. On this interpretation, the majority's mistake does not consist in comparing reasons wrongly; it consists in comparing reasons at all. To assert a non-comparative exclusion is to hold that the relevant comparison is impossible, not that it is wrongly made.

\footnotetext{
48 Id at 143.

49 Id at 144 .

${ }^{50}$ Id at 182-3 (Mosk J dissenting) (quoting Mary T. X 'Cells, Sales, \& Royalties: The Patient's Right to a Portion of the Profit' 6 Yale L $\mathcal{E}$ Poly Rev, 179, 190 (1990)).
} 
Which interpretation better represents Mosk's views? ${ }^{51}$ We can begin by noting that there is a serious problem with the 'compared wrongly' interpretation. The problem is that Mosk makes absolutely no attempt to show that the 'dignity' reasons to recognize the property right are better than the 'research' reasons not to. This aspect of Mosk's dissent baffles Justice Arabian:

I share Justice Mosk's sense of outrage, but I cannot follow the path. His eloquent paean to the human spirit illuminates the problem, but not the solution. Does it uplift or degrade the unique human persona to treat human tissue as a fungible article of commerce? Would it advance or impede the human condition, spiritually or scientifically, by delivering the majestic force of the law behind the plaintiff's claim? I do not know the answers to these troubling questions, nor am I willing - like Justice Mosk-to treat them ... as issues ... susceptible of judicial resolution. ${ }^{52}$

Justice Arabian's questions have considerable force-if we think Mosk is comparing reasons. If he is, Mosk's confidence is entirely misplaced when he claims that ' $[T]$ he dignity and sanctity with which we regard the human whole, body as well as mind and soul, are absent when we allow researchers to further their own interests without the patient's participation by using a patient's cells as the basis for a marketable product'. ${ }^{53}$ How does Mosk know that this is how the complex and controversial comparison of reasons finally comes out? Perhaps 'allowing researchers to further their own interests' would actually promote personal dignity as medical research not only saved lives but also prevented the degeneration and loss of dignity involved in the debilitating diseases that take their toll in old age.

The non-comparative exclusion interpretation makes this worry irrelevant. On this interpretation, Mosk has no need to explain why the comparison of reasons comes out a certain way: no comparison is involved. To assert the non-comparative exclusion is to claim that the relevant comparison is impossible. The question for us is, what kind of commitment would entail a non-comparative exclusion here? A closer reading of Mosk's dissent reveals the answer. In Mosk's eyes, the researchers treat Moore's body as an inanimate object to be exploited-a mine from which to extract ore, or a field from which to harvest a crop: the researchers claim 'the right ... to freely mine or harvest valuable physical properties of the patient's body'. ${ }^{54}$ More generally, Mosk compares the researcher's treatment of Moore to the violations of the body involved in torture, slavery, indentured servitude, and debtor's prison.

Focus on the analogy with torture. Imagine we capture a terrorist who has planted a bomb in a elementary school. Our problem is that we do not know which school, and, let us suppose, we can only find out by torturing the terrorist.

\footnotetext{
51 Mosk himself describes his approach as a straightforward balancing of reasons: 'in my view whatever merit the majority's single policy consideration may have is outweighed by two contrary considerations'. Id at 182 (emphasis added). For reasons that follow, I think Mosk misinterprets his own position.

52 Id at 164-5 (Arabian J concurring).

53 Id at 183.

54 Id.
} 
We have a reason to torture; torturing the terrorist is a means-the only means-of finding out where the bomb is. Of course, we also have reasons not to torture (the horrible pain, the grotesque violation of the value and dignity of persons). But, at least so $I$, and many others, think, ${ }^{55}$ we do not decide whether to torture by comparing the reasons for and against doing so-a comparison that would come out against torture only in some circumstances while favouring it in others. The value we place on persons prohibits deciding in this way; it creates an absolute and total ban on torture (or at least a nearly absolute and total ban). ${ }^{56}$ Instead, we proceed just as I did in the daughter-selling example; we exclude the reason to torture.

We should interpret Mosk as asserting a similar non-comparative exclusion. Mosk, as we have seen, likens the use made of Moore and his spleen to the violations of the body involved in torture, slavery, indentured servitude, and debtor's prison; he sees the doctors as violating Moore's bodily integrity by using him as a mine from which they extract 'genetic ore'. Given the weight Mosk places on these analogies, we should interpret him as holding that our commitment to the dignity and value of human beings excludes the research reasons as reasons to deny the property right. Many do value human beings and their bodies in such a way. Such an attitude informs much of Margaret Radin's work, for example. ${ }^{57}$ Of course, one may not be convinced that Mosk-as we have interpreted him-is correct. One may not find the analogies with torture, indentured servitude, and so on compelling; after all, just how is the voluntary removal of a spleen like torture or indentured servitude? Or, if one finds the analogies apt, one may be convinced-as the majority is-that recognizing a property right for Moore is simply unworkable, given the current state of medical research. Still, whatever one's ultimate position, the non-comparative exclusion issues raised in Mosk's dissent demand discussion. A court should not ignore them, as the majority does; or dismiss them, as the concurring Justice Arabian, who refuses 'to treat them ... as issues ... susceptible of judicial resolution'. ${ }^{58}$

\footnotetext{
55 See eg, Thomas Nagel, 'War and Massacre' in Thomas Nagel, Mortal Questions 110 (1979); for an extended discussion, criticism, and defence, see Samuel Scheffler, The Rejection of Consequentialism: $A$ Philosophical Investigation of the Conssiderations Underlying Rival Moral Conceptions (1982).

56 Compare Thomas Nagel:

'the constraints on action represented by rights cannot be equivalent to an assignment of a large disvalue to their violation, for that would make it permissible to violate such a right if by doing so one could prevent more numerous or more serious violations of the same right by others. This is not in general true. It is not permissible ... to kill an innocent person even to prevent the deliberate killing of three other innocent persons. A general feature of anything worthy of being called a right is that it is not translatable into a mere assignment of disvalue to its violation'.

Thomas Nagel 'Libertarianism Without Foundations' 85 Yale $L$ Rev 131, 144 (1975). Finnis makes a similar point. See Finnis, Absolutes above n 9 at 47-51. The puzzle, of course, is that many think we can 'violate ... a right if by doing so one could prevent more numerous or more serious violations of the same right by others'-provided the violations are very numerous and very serious. How is this consistent with not regarding rights as 'equivalent to an assignment of a large disvalue to their violation' in the less serious cases? We can put this puzzle to one side here.

${ }^{57}$ Radin insists, for example, that '[w]e feel discomfort or even insult, and we fear degradation or even loss of the value involved, when bodily integrity is conceived as a fungible object. Systematically conceiving of personal attributes as fungible objects is threatening to personhood, because it detaches from the person that which is integral to the person'. Radin, 'Inalienability' above n 9 at 1881.

${ }^{58}$ Id at 164-5 (Arabian J concurring).
} 
This is wrong. Laws governing crucial concerns in our lives should be informed by a proper appreciation of just what those concerns really are.

In fact, the law does not entirely ignore or dismiss the concerns animating Mosk's dissent. In the torts example, we see the law-or at least the Second Restatement-give great weight to just the sort of concern with the dignity of the human body that moves Mosk. We see this in the discussion of tort compensation in the Second Restatement. Let us first look at the discussion of compensation, and then see its connection to issues of non-comparative exclusion.

\section{Torts $^{59}$}

The Second Restatement takes two different attitudes toward compensation, corresponding to two different kinds of harm-harm to 'pecuniary interests' and 'bodily harm or emotional distress' ${ }^{60}$ In the case of pecuniary interests 'damages are designed to place [the person] in a position substantially equivalent in a pecuniary way to that which he would have occupied had no tort been committed' ${ }^{61}$ In the case of 'bodily harm or emotional distress', however,

the law cannot restore the injured person to his previous position. The sensations caused by harm to the body or pain or humiliation are not in any way analogous to a pecuniary loss, and a sum of money is not the equivalent of peace of mind.... There is no scale by which the detriment caused by the suffering can be measured and hence there can only be a very rough correspondence between the amount of awarded as damages and the extent of the suffering. ${ }^{62}$

In 'bodily harm or emotional distress' cases, damages are not intended to put the injured party 'in a position substantially equivalent in a pecuniary way to that which he would have occupied had no tort been committed'. ${ }^{63}$ An impossibility of comparison is the reason: 'The sensations caused by harm to the body or pain or humiliation are not in any way analogous to a pecuniary loss, and a sum of money is not the equivalent of peace of mind.... There is no scale by which the detriment caused by the suffering can be measured'.

Of course, this does not explicitly assert a non-comparative exclusion of reasons. The Restatement talks about the absence of a 'common scale' on which to measure psychic suffering against monetary amounts; it says nothing about an inability to compare reasons as better, worse, or equally good. We should nonetheless interpret the Restatement as asserting a non-comparative exclusion of reasons; otherwise, the Restatement's lack-of-a-common-scale claim collapses into the merely misleading and exaggerated acknowledgement that, when we award

\footnotetext{
${ }^{59} \mathrm{I}$ am indebted here to Peggy Radin. I intend my discussion to be complementary to her discussion of tort compensation in Radin 'Compensation' above $n$ 9. Sunstein also makes similar points about specific performance in contract law. See Sunstein above n 9, at 843-6.

${ }^{60}$ Restatement (Second) of Torts, Section 903 (1979).

61 Id comment a.

${ }^{62} \mathrm{Id}$.

${ }^{63}$ Id.
} 
monetary damages for psychic injury, we do compare injury to money but our comparisons are only rough and approximate.

The collapse comes because, when a court awards monetary compensation for torts involving bodily harm or emotional distress, the court must, to avoid objectionable arbitrariness, determine the amount in a principled way-in a way that, as far as possible, awards relevantly similar injuries relevantly similar amounts. How is the court to meet this requirement without using the extent of the injury as a measure-without, in the Restatement's words, establishing at least 'rough correspondence between the amount of awarded as damages and the extent of the suffering? ? ${ }^{64}$ It cannot. But to establish such a correspondence is to have a rough and approximate 'common scale', and this directly contradicts the Restatement claim that ' $[t]$ here is no scale by which the detriment caused by the suffering can be measured'. ${ }^{65}$

We can rescue the Restatement from this collapse into contradiction by turning to the non-comparative exclusion of reasons. To see the non-comparative exclusion analysis, consider selling body parts. Suppose you are offered $\$ 1,000,000$ for your arm. ${ }^{66}$ That is, the prospective purchaser will pay you to have it surgically removed and given to him. You have-let us suppose-reasons to have $\$ 1,000,000$. Of course, you also have a variety of reasons to keep your arm, and, in light of these reasons, you refuse the offer. There are two possible explanations of your refusal.

One is that you compare reasons-your reasons to keep your arm, and your reasons not to (the reasons to have the $\$ 1,000,000$ ); you find that the reasons to keep your arm are better. The price is simply not high enough. You measure the 'harm to the body' against the $\$ 1,000,000$ and find that the bodily harm outweighs the monetary gain. Perhaps some people would actually make the decision in this way. The point is not to argue that no one would; the point is to contrast the comparative approach with the alternative explanation of your refusal in terms of non-comparative exclusion, for that explanation shows us how to understand the Second Restatement. The alternative explanation is that you non-comparatively exclude the money as a reason to cut off your arm; you do not compare the reason to keep your arm to the reason not to keep it. You can correctly say that, for you, 'the sensations caused by harm to the body or pain or humiliation are not in any way analogous to a pecuniary loss, and a sum of money is not the equivalent of peace of mind.... There is no scale by which the detriment caused by the suffering can be measured $\ldots .{ }^{67}$ Why would you

\footnotetext{
${ }^{64}$ Id.

${ }^{65} \mathrm{Id}$.

${ }^{66}$ Compare Radin, 'Compensation' above $\mathrm{n}$ 9: 'When someone who has lost an arm in an accident receives $\$ 100,000$ in compensation through the tort system, what does this transaction mean? Does it mean that an arm is "worth" $\$ 100,000$ ? ... I am writing about meaning - the way human interactions are understood by a community sharing a concept in practice. The concept $I$ focus on in compensation, in particular compensation for personal injury' Id at 56. The example in the text has a similar aim; it focuses on the 'meaning' of getting money for limbs, but it does so not from the point of view of tort compensation, but from the point of view of selling a limb. We will use the perspective we develop on this transaction to understand the practice of tort compensation.

${ }_{67}$ Restatement (Second) of Torts $\$ 903 \mathrm{cmt}$ a (1979).
} 
non-comparatively exclude the reasons? For the reasons similar to those we attributed to Mosk in Moore: a commitment to valuing persons and their bodies that prohibits regarding the reason to have the $\$ 1,000,000$ as a reason to cut off one's arm. ${ }^{68}$ We can explain the Second Restatement's position on damages for bodily harm and emotional distress if we see the Restatement as endorsing a similar non-comparative exclusion claim. I am not, of course, suggesting that the authors of the Restatement explicitly thought in terms of non-comparative exclusion; rather, the non-comparative exclusion interpretation provides an illuminating perspective on the Restatement, a perspective that provides a satisfying explanation for its position on damages. But then what should we say about the fact that, in awarding damages for bodily harm and emotional distress, we can-and indeed must-establish a 'rough correspondence between the amount of awarded as damages and the extent of the suffering? ${ }^{69}$ There is no real difficulty here. We can award money for bodily harm or emotional distress while still recognizing the non-comparative exclusion as reason to suffer injury to the body. The injury makes the injured party's life worse in a certain way; we can respond to the injury by making the life better in another-monetary-way; and, the worse the injury, the greater we can make the monetary award. Given that we cannot make the person whole, awarding money may be the 'second best' alternative. Opting for this second-best does not mean we think, for example, that the reasons to have the money are also reasons to accept injury to one's body or mind. It just means that, in a far from ideal world, imperfect justice is the best and most humane justice we have. ${ }^{70}$

The torts example shows the law refusing to compare reasons, even where, to avoid arbitrariness in awards, we must, establish a 'rough correspondence between the amount of awarded as damages and the extent of the suffering'. We could use this 'rough correspondence' as a way of comparing reasons-if our values permitted it. But they do not. They do not allow us to count the reasons to have the money as reasons to endure the bodily or psychic injury.

\section{Contract Law}

The contract law example illustrates another situation in which a workable comparison of reasons would be possible-if our commitments permitted it. The doctrine of impracticability provides the example. The doctrine is that a promisor may be excused from performance under two conditions: first, an unexpected contingency makes performance commercially impracticable-ie, especially

\footnotetext{
68 Margaret Radin adopts essentially this position, although she does not express herself in terms of noncomparative exclusion. I am discussing Radin's views in Radin 'Inalienability' above $n$ 9. In that article, she does not express herself in terms of non-comparative exclusion; she turns explicitly to this notion in Radin, 'Compensation' n 9.

69. Restatement (Second) of Torts $\$ 903 \mathrm{cmt}$ a (1979).

70 Radin reaches essentially the same conclusion in Radin 'Compensation' above $n$ 9: 'If we do conceive of compensation in primarily a noncommodified way-if we are clear that it is not a quid pro quo, but rather a symbolic action that reinforces our commitments about rights and wrongs-then the practice of paying compensation does not signify that we conceive of the harm to persons for which we pay it as commodities'. Id at 85 .
} 
difficult or impossible; and, second, it is not the case that the promisor seeking to be excused ought to bear the risk of loss from such a contingency. ${ }^{71}$ The first condition identifies a threshold requirement. Once this requirement is fulfilled, then-and only then-does it become relevant whether the reasons the contingency provides are better than the reasons one has to keep the promise. The second condition indicates that this is a matter of risk assignment; one must show that one ought not to bear the risk of loss from the contingency.

Why should the doctrine have this two-tier structure? It is irrational-unless we recognize a relevant non-comparative exclusion. To see why, suppose that I am wholesaler of hair gel. I promise to supply you (a hair gel retailer) with all the hair gel you need at $\$ 1$ a tube. Unexpectedly, the costs of making hair gel rise sharply with the result that I am just breaking even on our contract. I have a reason to stop selling you hair gel for $\$ 1$ a tube-namely, I am not making any money by doing so, and, were I not selling to you, I could sell to another buyer who is willing to pay more. ${ }^{72}$ Not selling to you means breaking my promise. So, my reason to stop selling to you (namely, that I am just breaking even) is also a reason to break my promise. Of course, I also have reasons not to break my promise. After all, I promised, and, typically at least, giving one's word places one under an obligation to keep it (and I may, of course, have other reasons such as preserving my business reputation). I compare the reasons as better, worse, or equally good. Imagine I do so; find the reason to break the promise to be better, and accordingly breach my contract with you.

When you sue me for breach of contract, why should I not be able to argue, under impracticability doctrine, that I am excused from my contractual obligations on the ground that the rise in costs made it rational for me to break my contract? After all, given appropriate circumstances, the comparison of reasons might show that it was rational for me to break my contract. ${ }^{73}$ For example, suppose I could show that my breach would save me money and benefit you - eg, because my breach would allow you to obtain a long-term contract with another supplier that, over time, would be better than anything I could give you.

Can I present this comparison of reasons under impracticability doctrine? No. Under current impracticability doctrine, although the rise in costs was unexpected, it does not make performance commercially impracticable. ${ }^{74} \mathrm{I}$ do

\footnotetext{
71 See E. Allan Farnsworth, Contracts 677-89 (1982).

72 If the second buyer is willing to pay sufficiently more, my breach will be 'economically efficient'. The idea is that it is rational for a party to breach a contract to contract to deal with another instead if the breacher can compensate the other party and still make a profit on the second contract. See Peter Linzer, 'On the Amorality of Contract Remedies-Efficiency, Equity, and the Second Restatement' 81 Colum L Rey 111 (1981) (for a general discussion and criticism of the idea of an efficient breach), and lan McNeil, 'Efficient Breach of Contract: Circles in the Sky' $68 \mathrm{Va} L \mathrm{Rev} 947$ (1982) (criticizing the notion of an efficient breach). The theory of efficient breach, like economic analysis generally, assumes that reasons for action are generally comparable.

${ }_{73}$ This is the claim behind the theory of the efficient breach. See above $\mathbf{n} 72$.

${ }^{74}$ Unilorm Commercial Code $\ 2-615$, Official Comment 4 says: 'Increased cost alone does not excuse performance unless the rise in cost is due to some unforeseen contingency which alters the essential nature of the performance. Neither is a rise or a collapse in the market in itself a justification, for that is exactly the type of business risk which business contracts made at fixed prices are intended to cover'.
} 
not meet the threshold test of the first condition, and I cannot argue that I should not bear the entire loss from the unexpected contingency. The law excludes my reasons to break my promise. Why does it do so? We can explain the exclusion by focusing on the fact that I make a promise.

In making my promise, I make a commitment that entails a non-comparative exclusion. As John Finnis notes, '[a] promise properly made is always an exclusionary reason, that is, always gives a reason for disregarding some reasons, which are genuine and relevant and which, in the absence of the promise to [perform the action] would have sufficed to justify not [performing the action]. ${ }^{.75}$ Consider an example. Suppose I promise to accompany you to the doctor on Tuesday; you face a possible diagnosis of cancer and want moral support. However, when Tuesday arrives, it is a beautiful day, and I think that it would be quite enjoyable to take a walk. However, since I promised, I cannot (cannot properly) count considerations like the prospect of an enjoyable walk as a reason not to do as I promised. Of course, one can promise and still properly regard some considerations as reasons to break the promise. I may have sufficient reason to break my promise if, through no fault of my own, accompanying you means leaving my two-year-old daughter unattended in a city park. The point is that having an adequate reason to break a promise is a two-stage matter. First, the considerations in question reason must be the kind of considerations that, in the circumstances, can be such a reason-eg, the safety of a young child, as opposed to the enjoyment of a walk. Second, the reason provided by those considerations must be better than the reasons to keep the promise. This is why we see a twotier structure in the doctrine of impracticability. The first condition-the threshold condition-reflects the fact that one needs a certain kind of reason to break a promise. ${ }^{76}$

Similar remarks hold for various other contract doctrines: frustration, mistake, duress, undue influence, unconscionability. These doctrines all contain a component that defines what does and does not count as a reason to break a promise. Delineating such reasons is one function-one of the main functions-of contract . law.

\section{Conclusion}

The preceding examples illustrate the place of non-comparative exclusion in the law, but they do not provide what many may feel a need for: a general and

\footnotetext{
${ }^{75}$ Finnis, Natural Law above n 9 at 308. Scheffler above n 55 at 85 n. 2 offers a similar characterization of promising.

${ }_{76}$ I am assuming that contracts involve promises. Some may challenge this. Consider the hair gel example again. Did $I$ promise-promise in the sense that bars me from considering just breaking even as a reason to break my promise? It is certainly possible for parties to enter a contractual relationship which does not have this character. We might-explicitly or implicitly-agree that I should, in the above situation, sell for more money and share some of the additional profit with you by way of compensation for my breach. Former California Chief Justice Rose Bird argued for just such a view of commercial contracts in Seaman's Direct Buying Service v Standard Oil Co $36 \mathrm{Cal}$ 3d. 752, (1984) (Bird J dissenting). But one must be careful here. Commercially contracting parties typically each commit to co-ordinating their behaviour for their mutual benefit. If this commitment excludes no reasons at all, in what sense is it a commitment?
} 
informative prescription that explains how we should systematically incorporate non-comparative exclusion into public decision-making. This felt need must go unsatisfied. To attempt to formulate such a general prescription would be selfdefeating. Non-comparative exclusion is the domain of the particular and the individual, not the general and the systematic. The point is to provide a counterpoint to systematic attempts to catalogue and compare reasons, attempts like the EPA's risk analysis approach that, in insisting on comparing reasons, ignore the seif-defining commitments that entail non-comparative exclusions. As Iris Murdoch writes, "We know the real lesson to be taught is that the human person is precious and unique; yet we seem unable to set it forth except in terms of ideology and abstraction' ${ }^{77}$ The point of emphasizing non-comparative exclusion is to avoid the seemingly inevitable 'ideology and abstraction'.

Instead of engaging in the doomed attempt to give a general, systematic, and informative account of the proper role of non-comparative exclusion in public decision-making, let us focus on residual resistance to recognizing non-comparative exclusion. Despite all that we have said, it may still seem to some that rational public policy-making requires comparing reasons-even if individual rational choice, as in the daughter-selling-example, does not always do so. Reflection on examples may make this point seem compelling. Consider courts. Courts are institutions the State designates to decide a certain range of disputes; typically, the disputing parties argue for different decisions, each side offering reasons for it's position (of course, the court is not limited to the reasons the parties advance; it may also consider reasons of its own). The court's institutional responsibility is to ensure that an adequate consideration of legally relevant reasons guides its decision-making process. So much is beyond controversy. ${ }^{78}$ Now it may seem equally beyond controversy that 'adequately considering' reasons means comparing them. ${ }^{79}$ Imagine a motion for a preliminary injunction. One side provides reasons not to grant the injunction (eg, reasons for thinking money damages would be adequate); the other side, reasons to grant it (eg, reasons for thinking money damages would not be adequate). Surely, the court should decide by determining whether the reasons to deny the injunction are better or worse than the reasons to grant it.

Examples of non-judicial decision-making can seem equally compelling:

Due to budgetary restrictions, a town must decide whether to cut funding for the schools, the fire department, or the police department, although the needs for all three

\footnotetext{
${ }_{77}$ Murdoch above $\mathrm{n} 1$.

78 Ronald Dworkin, for example, emphasizes that 'the author of a judicial decision accepts the responsibility, among others, to explain, particularly to those adversely affected, why different treatment of others in other circumstances is not capricious or arbitrary or discriminatory', Ronald Dworkin, Taking Rights Seriously (1966) 373-7.

${ }_{79}$ The most explicit and persuasive picture of judicial decisions as a matter of comparing reasons is in Steven Burton's excellent book, Burton fudging above $\mathrm{n} 2$. Burton does not discuss non-comparative exclusion. He could accommodate non-comparative exclusion within his framework, but doing so would require changes in his account of how legal decision-makers weigh reasons. For Burton's account of weighing reasons, see id at 54-68. For an overview of Burton on weighing reasons, see Richard Warner, 'Review of Steven Burton fudging in Good Faith', Ethics, forthcoming.
} 
services are urgent and increasing. While in some circumstances the rankings might be fairly easy to make, it is equally easy to imagine circumstances in which individuals might find it difficult or impossible to make them, for instance when the town's desire to fund each service is supported by weighty, but very different reasons. ${ }^{80}$

Pildes and Anderson offer this example in their critique of social choice theory where they claim that the 'very different' reasons are incommensurable ('the rankings [are] ... impossible to make'). ${ }^{81}$ Suppose-arguendo-that the reasons cannot be compared, and suppose also that the town decides to fund the schools as opposed to the police. How will it justify its decision to the proponents of funding the police? Of course, it can cite the reasons it had for funding the schools, but what will it say when the police-proponents ask why those reasons were better than the reasons for funding the police? If the reasons are cannot be compared, the town cannot answer this question. But aren't the proponents of funding the police entitled to an answer, an answer based on a comparison?

How can we explain the apparent compellingness of the conviction that comparison is required? I suggest that we concede that, in public decisionmaking, comparison is often-but not always-required. Focusing on the cases in which comparison is called for can create the illusion that rational public decision-making always requires the comparison of competing reasons. The 'often, but not always' requirement of comparison arises out of a concern with legitimacy. As Steve Burton notes, '[i]n a society that cares about justice ... decision making based on reason ..., not preference or faith, is crucial for legitimacy'. 82 To compare reasons is to meet this requirement in a particularly satisfying way; it provides a satisfying answer to the question, 'Why this policy and not some other?' We can answer that the reasons for the policy are better than the reasons for competing policies.

We need not pursue these issues. Instead, let us concede-at least arguendothat rational public decision-making does indeed often require the comparison of reasons. This does not mean that non-comparative exclusion is irrelevant to public policy making - quite the contrary. The town-budget example illustrates the point. Suppose that, given the severe budgetary constraints, rational choice requires comparing reasons, but suppose also that the citizens of the town share commitments that make the opposing sets of reasons impossible to compare. They are committed to education in a way that excludes financial considerations

\footnotetext{
${ }^{80}$ Pildes \& Anderson above $\mathrm{n} 9$ at 2160.

81 Pildes and Anderson, actually say that 'individuals might find it difficult or impossible to make' the rankings. This is a mistake. Mere difficulty is insufficient to show impossibility-even if the difficulty is so great that we could characterize it as practically impossible to make the comparison. Impossibility of comparison is not a matter of comparison being difficult; it is a matter of it being impossible. On another point, some may object that Pildes and Anderson describe the alternative choices, as opposed to the reasons for them, as incommensurable; but clearly, where our concern is to rank alternatives from most to least choice-worthy, it is the reasons that matter. Indeed, the alternatives are incommensurable when (and only when) the reasons are. Proof: when the reasons are commensurable, so are the alternatives: the best alternative is the one backed by the best reasons; when the reasons-the grounds for choice-are incommensurable, then so are the alternatives since we lack any basis on which to rank the alternatives in terms of choice-worthiness.

${ }_{82}$ Steve Burton, 'Reaffirming Legal Reasoning: The Challenge from the Left' $36 \mathrm{~J}$ Legal Educ at 358, 368 (1986).
} 
as reasons to forego providing certain educational basics, and they are also committed to public safety in a way that excludes financial considerations as reason to forego providing a basic level of police protection. They cannot adhere to these commitments and compare reasons; they must reinterpret their commitments so as to allow comparison.

Where comparison is required, non-comparative exclusion inevitably casts public decision-makers in the role of reinterpreters of our commitments. This aspect of non-comparative exclusion runs through many of the topics we listed at the beginning-bankruptcy, contracts, environmental law, family law, free speech, torts, racial discrimination, and sexual equality. Take sexual equality and environmental law. In rectifying unjust discrimination based on race and gender, we regard race and gender as reasons to choose one person over another in employment. We also have, or have had, a conception of social equality that makes various differences-such as race and gender-irrelevant to access to employment; our-previous, but now altered?-conception of social justice excluded race and gender as reasons. As for the environment, many, as we noted earlier, 'feel extremely insulted when asked how much [money] they would accept for a specified level of environmental deterioration, treating the question as outrageous or a form of bribery, rather as if they had been asked to sell a child or a part of their body'. ${ }^{83}$ Yet, just as in our imagined town-budget example, econcmic reality - for example, the need to allow industrial development crucial to a healthy economy - often compels us to trade environmental health for economic health. In doing so, we count as reasons considerations we previously excluded.

The essential point is that pressures on public decision-making force reinterpretations of some of our most fundamental non-comparative exclusioncreating commitments. ${ }^{84}$ This essay is a plea to make this process one that self-consciously acknowledges the place of those commitments. Decisions that profoundly affect central concerns in our lives should be informed by a proper appreciation of what those concerns really are.

\footnotetext{
83 Sunstein above $n$ 3, at 835 .

${ }^{84}$ See the excellent discussion in Michael Shapiro, 'Regulation as Language: Communicating Values By Altering the Contingencies of Choice' $55 U$ of Pitt $L$ Rev 681, 760-90 (1994). Shapiro discusses commodification, not non-comparative exclusion, but his discussion illustrates the pressures and considerations that motivate decision by compraring reasons.
} 